\title{
Pengaruh Pelatihan Komunikasi Interpersonal Terhadap Efikasi Diri Sebagai Pelatih pada Mahasiswa
}

\section{The Effect of Interpersonal Communication Training in Improving Self Efficacy as a Trainer Among College Students}

\author{
Miftahun Ni'mah Suseno* \\ Fakultas Psikologi dan IImu Sosial Budaya UII, Yogyakarta 55584
}

Diterima 6 Mei 2009 / Disetujui 20 Mei 2009

\begin{abstract}
This experiment examines the influence of interpersonal communication training in improving self efficacy as a trainer among college students. The hypothesis was that there is a significant difference in self efficacy of a trainer between the experimental and control group. There is also significant difference in self efficacy of a trainer among participants in experimental group between pre and post experiment. The participants of this experiment are college students with age ranging from 21 to 23 years old. The design of this experiment was Pretest Posttest with Control Group Design. A measure of self efficacy was developed by using aspect from Bandura (1997). The training module was developed on the basis of Hardjana Theory (2003). Data were analyzed using gain score method. The result shows that there is a difference in self efficacy of a trainer between experimental and control group $(t=16.989 ; p<0.01)$. This means that the interpersonal communication training show influences in increasing self efficacy of a trainer. An experiment group data analysis shows that there is a difference in self efficacy prior and after the training $(t=-16.819 ; p<0.01)$. The result of this experiment confirmed the hypothesis.
\end{abstract}

Keywords: interpersonal communication, self efficacy, trainer.

Kesiapan kerja (employability) merupakan hal yang sangat penting bagi lulusan perguruan tinggi serta institusi perguruan tinggi itu sendiri. Lulusan perguruan tinggi akan lebih cepat dan mudah mendapatkan pekerjaan yang diinginkan apabila memiliki kesiapan kerja sesuai dengan latar belakang bidang studinya. Kesiapan kerja mengacu pada kapasitas dan kemauan individu untuk dapat tetap menonjol dalam pasar kerja (Carbery \& Garavan, 2005). Hal tersebut menunjukkan bahwa untuk dapat tetap menonjol dalam persaingan pasar kerja dan mendapatkan pekerjaan yang diinginkan, individu tidak hanya harus memiliki kemauan yang kuat, tetapi juga kapasitas dalam bekerja yaitu sejumlah keterampilan kerja yang

\footnotetext{
* Penulis Korespondensi :

Telp. (0274) 898444, HP. 081928021277,Email : miftahun_a@yahoo.com
} 
dibutuhkan berbagai perusahaan. Yorke dan Harvey (2005) menyatakan pemberi kerja (employer) tidak hanya mencari pekerja yang mampu beradaptasi, fleksibel, dan memiliki keinginan untuk terus belajar, namun juga menginginkan pekerja yang memiliki keterampilan komunikasi, bekerja dalam tim, serta mahir dalam menggunakan teknologi informasi dalam menjalankan perusahaan.

Mahasiswa sebagai aset lulusan perguruan tinggi seringkali dihadapkan pada pilihan karir tertentu setelah menempuh pendidikan. Mahasiswa sebagai pasar tenaga kerja dituntut untuk mempunyai ketrampilan dan kesiapan kerja (employability) sesuai dengan bidangnya. Namun kenyataan menunjukkan bahwa banyak mahasiswa yang merasa kurang mempunyai kompetensi yang cukup untuk mengaplikasikan ilmu yang sudah diperolehnya.

Menjadi seorang pelatih merupakan salah satu karir yang dapat ditempuh oleh mahasiswa khususnya mahasiswa psikologi. Untuk menjadi pelatih (trainer), mahasiswa dituntut untuk memiliki efikasi diri (self efficacy) bahwa ia mampu menjadi seorang pelatih, karena dengan adanya efikasi diri yang tinggi maka mahasiswa akan memiliki keyakinan terhadap kemampuan yang dimilikinya.

Ketrampilan dasar yang harus dikuasai oleh pelatih adalah kemampuan komunikasi interpersonal. Winkel (Barus, 2005) menegaskan bahwa komunikasi interpersonal merupakan proses komunikasi timbal balik yang berlangsung antara dua orang atau lebih secara tatap muka, langsung, dan melalui kontak pribadi. Hardjana (2003) mendefinisikan bahwa komunikasi interpersonal adalah interaksi tatap muka antara dua atau beberapa orang, dimana pengirim dapat menyampaikan secara langsung, dan penerima pesan dapat menerima dan menanggapi secara langsung pula. De Vito (1997) menyatakan bahwa komunikasi interpersonal merupakan proses pengiriman dan penerimaan pesan antara dua orang atau antara sekelompok kecil orang secara spontan dan informal. Pada saat terjadi komunikasi interpersonal maka akan muncul pemahaman dalam berkomunikasi dan selanjutnya akan terjalin hubungan antar individu yang melibatkan proses psikologis. Komunikasi interpersonal merupakan ketrampilan dasar yang harus dimiliki oleh seseorang, karena dengan keterampilan komunikasi interpersonal maka seseorang akan mampu menyampaikan pesan kepada orang lain dan dapat menjalin hubungan dengan orang lain. Komunikasi interpersonal sangat dibutuhkan pada diri seorang pelatih, karena di dalam sebuah pelatihan (training), pelatih dituntut untuk dapat menyampaikan pesan dan menerima pesan atau pertukaran makna antara pelatih dan peserta pelatihan (trainee) yang bertemu secara langsung dalam proses pelatihan, dan akan terjadi umpan balik sehingga tercapai saling pengertian mengenai apa yang dibicarakan. 
Peningkatan komunikasi interpersonal diharapkan membantu mahasiswa untuk mempunyai keterampilan dasar yang dibutuhkan sebagai seorang pelatih, sehingga akan muncul keyakinan dalam dirinya bahwa ia mampu menjadi seorang pelatih dan akan memilih pelatih menjadi orientasi karirnya. Melihat pentingnya komunikasi interpersonal dalam meningkatkan efikasi diri sebagai pelatih pada diri mahasiswa, maka mahasiswa harus dibekali ketrampilan komunikasi interpersonal sebagai kompetensi dasar yang harus dimiliki oleh seorang pelatih. Penelitian ini mencoba untuk mengetahui pengaruh pelatihan komunikasi interpersonal terhadap efikasi diri sebagai pelatih pada diri mahasiswa.

Efikasi diri, menurut Bandura (1997), adalah keyakinan diri seseorang akan kemampuan-kemampuannya untuk mengatur dan melaksanakan serangkaian tindakan yang diperlukan untuk menghasilkan suatu hal. Efikasi diri merupakan penilaian terhadap kemampuan diri seseorang. Disebutkan bahwa efikasi diri mengacu pada harapan yang dipelajari seseorang bahwa dirinya mampu melakukan suatu perilaku ataupun menghasilkan sesuatu yang diharapkan dalam suatu situasi tertentu (Schunk, dalam Feldman 1997). Bandura (1997) menyatakan bahwa efikasi diri merupakan perasaan, penilaian seseorang mengenai kemampuan dan kompetensi yang dimiliki untuk menyelesaikan tugas yang diberikan kepadanya.

Menurut Pajares (Woolfolk, 2004), efikasi diri adalah penilaian terhadap kompetensi diri dalam melakukan suatu tugas khusus dalam konteks yang spesifik. Selanjutnya efikasi diri diartikan dengan fokus pada kemampuan seseorang untuk dapat menyelesaikan sejumlah tugas dengan sukses (Woolfolk, 2004). Myers (2005) mengungkapkan bahwa efikasi diri adalah perasaan yang dimiliki seseorang bahwa dirinya kompeten dan efektif dalam melakukan suatu tugas.

Locke, dkk. (Dimyati, 1984) mengatakan bahwa efikasi diri yang tinggi akan menumbuhkan rasa percaya diri akan kemampuan dirinya dalam melaksanakan tugas. Bandura (1997) mengatakan bahwa keyakinan akan seluruh kemampuan ini meliputi kepercayaan diri, kemampuan menyesuaikan diri, kapasitas kognitif, kecerdasan dan kapasitas bertindak pada situasi yang penuh dengan tekanan. Orang yang ekspektasi efikasinya tinggi dan harapan hasilnya realistik maka orang tersebut akan bekerja keras dan bertahan mengerjakan tugas sampai selesai (Alwisol, 2006). Percaya terhadap keyakinan diri atau efikasi diri merupakan faktor kunci dalam perantara hidup. Menurut Bandura (1997), jika seseorang percaya bahwa ia tidak memiliki kekuatan untuk memproduksi suatu hasil, maka orang tersebut tidak akan berusaha untuk membuat sesuatu terjadi. Sebaliknya orang yang memiliki efikasi diri tinggi diyakini sebagai orang yang mampu berperilaku tertentu untuk dapat 
mencapai hasil yang diinginkan, dan mereka juga lebih giat dan lebih tekun dalam berusaha.

Menurut Bandura (1997), terdapat tiga komponen yang memberikan dorongan bagi terbentuknya efikasi diri, yaitu: (a) Pengharapan akan hasil (Outcome expectancy), yaitu adanya harapan terhadap kemungkinan hasil dari perilaku. Harapan ini dalam bentuk prakiraan kognitif tentang kemungkinan hasil yang akan diperoleh dan kemungkinan tercapainya tujuan. (b) Pengharapan akan efikasi (Efficacy expectancy), yaitu harapan atas munculnya perilaku yang dipengaruhi oleh persepsi seseorang pada kemampuan kinerjanya yang berkaitan dengan hasil. Jika seseorang sering mengalami kegagalan pada suatu tugas tertentu maka ia cenderung memiliki efikasi yang rendah pada tugas tersebut. Sebaliknya, jika menemukan keberhasilan dalam melakukan tugas tertentu maka ia akan mempunyai efikasi diri yang tinggi pada tugas tersebut. (c) Nilai hasil (Outcome value), yaitu nilai kebermaknaan atas hasil yang diperoleh seseorang. Nilai hasil yang sangat berarti akan memberikan pengaruh yang kuat pada motivasi seseorang untuk mendapatkannya kembali.

Efikasi diri, menurut Bandura (1997), memiliki tiga dimensi yaitu, (a) tingkat kesulitan tugas (magnitude), (b) luas bidang perilaku (generality), dan (c) kemantapan keyakinan (strength). Pertama, tingkat kesulitan tugas yaitu berhubungan dengan tingkat kesulitan suatu tugas. Individu akan mencoba perilaku yang dirasa mampu dilakukan dan akan menghindari situasi dan perilaku yang diluar batas kemampuan yang dirasakan. Jika seseorang dihadapkan pada tugas yang disusun menurut tingkat kesulitan, maka efikasi diri akan diarahkan pada tugas yang mudah, sedang atau sulit sesuai dengan batas kemampuan yang dirasakan untuk memenuhi tuntutan perilaku yang dibutuhkan masing-masing tingkatan kesulitan. Kedua, luas bidang perilaku merupakan dimensi yang berhubungan dengan luas bidang perilaku. Beberapa pengharapan terbatas pada bidang tingkah laku yang khusus dan beberapa pengharapan mungkin menyebar meliputi berbagai bidang tingkah laku. Luas bidang perilaku (generality) ialah sejauh mana individu yakin akan kemampuannya dalam berbagai situasi tugas, mulai dari saat melakukan suatu aktivitas atau situasi tertentu hingga dalam serangkaian tugas atau situasi yang bervariasi. Terakhir, kemantapan keyakinan (strength) adalah derajat kemampuan individu terhadap keyakinan atau pengharapannya. Seseorang dengan efikasi diri yang lemah akan mudah menyerah pada pengalamanpengalaman yang tidak menunjang. Sedangkan seseorang dengan efikasi diri tinggi akan mendorong individu untuk tetap bertahan dalam usahanya walaupun ditemukan pengalaman yang tidak menunjang atau menghambat.

Efikasi diri merupakan keyakinan dalam diri seseorang tentang sejauh mana seseorang memperkirakan kemampuan dirinya dalam melaksanakan suatu tugas atau 
tindakan yang diperlukan untuk mencapai hasil selanjutnya. Seseorang yang mempunyai efikasi diri tinggi akan berperilaku tertentu untuk mencapai hasil yang diinginkan, lebih giat dan lebih tekun dalam berusaha. Saat menghadapi kendala atau kesulitan, seseorang dengan efikasi diri tidak akan mudah menyerah, tidak mudah cemas, jarang kecewa. Sebaliknya seseorang dengan efikasi diri rendah cenderung kurang mampu mengarahkan perilakunya untuk mencapai tujuan yang ditargetkan, memiliki keraguan akan kemampuan dirinya dan apabila menghadapi kendala akan cenderung mudah putus asa dan menyerah dengan keadaan.

Efikasi diri sebagai pelatih dibutuhkan oleh mahasiswa yang menjadikan profesi pelatih sebagai orientasi karimya. Dengan memiliki keyakinan diri (efikasi diri) sebagai seorang pelatih maka ia akan memunculkan perilaku yang gigih, bersemangat dan ingin berprestasi di bidang pelatihan, menjadi sosok pelatih yang handal, dan akan berusaha maksimal untuk menjadi seorang pelatih. Guna memunculkan adanya efikasi diri sebagai pelatih pada mahasiswa maka dibutuhkan keterampilan komunikasi interpersonal yang baik, karena dalam sebuah pelatihan, peran pelatih adalah menyampaikan pesan kepada peserta pelatihan secara efektif sehingga perubahan sikap dan perilaku yang diharapkan dari pelatihan tersebut dapat tercapai. Dengan adanya keterampilan komunikasi interpersonal yang dimiliki mahasiswa maka diharapkan akan meningkatkan efikasi dirinya sebagai pelatih. Pelatihan komunikasi interpersonal ini diharapkan mampu memberikan dorongan terbentuknya efikasi diri sebagai pelatih, yaitu memunculkan harapan akan kemungkinan hasil dari perilaku (outcome expectancy), harapan munculnya perilaku yang dipengaruhi oleh persepsi pada kemampuan kinerjanya yang berkaitan dengan hasil (efficacy expectancy) dan nilai kebermaknaan atas hasil yang diperoleh seseorang (outcome values).

Berdasarkan uraian di atas, maka penelitian ini memiliki dua hipotesis. Pertama, ada perbedaan efikasi diri sebagai pelatih antara kelompok eksperimen dan kelompok kontrol. Kelompok eksperimen lebih tinggi efikasi dirinya sebagai pelatih daripada kelompok kontrol. Kedua, ada perbedaan efikasi diri sebagai pelatih antara sebelum dan sesudah mengikuti pelatihan komunikasi interpersonal.

\section{Metode Penelitian}

\section{Subjek Penelitian}

Subjek penelitian adalah mahasiswa Fakultas/Program Studi Psikologi di salah satu PTS yang ada di wilayah Yogyakarta dan mempunyai karakteristik berusia antara 21 sampai dengan 23 tahun, baik laki-laki maupun perempuan. Subjek dibagi dalam dua kelompok, yaitu 
kelompok eksperimen dan kelompok kontrol. Kelompok eksperimen diberi perlakuan berupa pelatihan komunikasi interpersonal sedangkan kelompok kontrol adalah kelompok daftar tunggu (waiting list), artinya kelompok ini akan diberi pelatihan seusai pengukuran pasca pelatihan pada kelompok eksperimen dan seteleh perlakuan diberikan pada kelompok kontrol tidak akan dilakukan pengambilan data setelah pemberian perlakuan tersebut.

\section{Rancangan Penelitian}

Metode yang digunakan dalam penelitian ini adalah metode eksperimen, dengan rancangan eksperimen rancangan eksperimen prates-pascates kelompok kontrol (pretestposttest with control group design). Di bawah ini disajikan bentuk rancangan eksperimen.

Tabel 1. Bentuk Rancangan Eksperimen

\begin{tabular}{lccc}
\hline \multicolumn{1}{c}{ Subjek } & Prates & Perlakuan & Pascates \\
\hline Kelompok Ekperimen & Y1 & $X$ & Y2 \\
Kelompok Kontrol & Y1 & - & Y2 \\
\hline
\end{tabular}

Keterangan:

Y1 : Pengukuran sebelum perlakuan diberikan

$X$ : Perlakuan yang diberikan

Y2 : Pengukuran setelah perlakuan diberikan

\section{Pengumpulan Data}

Penelitian ini menggunakan beberapa alat dalam pelaksanaannya antara lain; skala efikasi diri sebagai pelatih yang disusun berdasarkan aspek efikasi diri menurut Bandura (1997) yang terdiri dari 30 item dengan koefisien korelasi item-total bergerak dari $0,3650,561$ dan mempunyai koefisien reliabilitas alpha sebesar 0,911. Skala ini terdiri dari 15 item favorabel dan 15 item nonfavorabel. Pemberian nilai dalam skala ini menggunakan metode Likert dengan modifikasi alternatif jawaban yang hanya terdiri dari 4 pilihan jawaban yaitu sangat sesuai, sesuai, tidak sesuai dan sangat tidak sesuai. Proses skoringnya adalah untuk item favorabel jawaban sangat sesuai diberi skor 4 , sesuai diberi skor 3 , tidak sesuai diberi skor 2, dan sangat tidak sesuai diberi nilai 1, sedangkan untuk item nonfavorabel jawaban sangat sesuai diberi skor 1 , sesuai diberi skor 2 , tidak sesuai diberi skor 3 , dan sangat tidak sesuai diberi nilai 4 . 


\section{Intervensi}

Pelatihan adalah kegiatan yang dirancang untuk meningkatkan kinerja seseorang dalam pekerjaan yang diserahkan kepada mereka (Hardjana, 2001). Pelatihan komunikasi interpersonal dirancang dengan menggunakan metode belajar melalui pengalaman (experiential learning). Peristiwa di dalam kehidupan dapat distimulasikan melalui suatu permainan yang dapat dirasakan secara langsung oleh peserta pelatihan (Ancok, 2002).

Materi. Pelatihan Komunikasi Interpersonal adalah salah satu program pelatihan yang disusun dengan tujuan untuk mengasah keterampilan seseorang dalam melakukan komunikasi interpersonal sehingga seseorang mempunyai kecakapan sosial dan kecakapan behavioral. Modul pelatihan didasarkan pada teori komunikasi interpersonal dari Hardjana (2003) yang menyatakan bahwa komunikasi interpersonal adalah interaksi tatap muka antara dua atau beberapa orang, dimana pengirim dapat menyampaikan secara langsung, dan penerima pesan dapat menerima dan menanggapi secara langsung pula. Pelatihan komunikasi interpersonal ini akan menggunakan 11 aspek yang dibutuhkan seseorang agar komunikasi interpersonal berhasil yaitu kecakapan sosial yang meliputi keterampilan dalam hal empati, perspektif sosial, kepekaan, pengetahuan akan situasi komunikasi dan memonitor diri. Sedangkan kecakapan dalam berperilaku meliputi keterlibatan interaktif, manajemen interaksi, keluwesan perilaku, mendengarkan, gaya sosial dan kecemasan komunikasi.

Pelaksanaan. Setelah menentukan subjek penelitian, dilakukan prates dengan menggunakan skala efikasi diri sebagai pelatih, kemudian dilakukan pengelompokkan secara random (random assignment) untuk mengelompokkan ke dalam kelompok eksperimen dan kelompok kontrol. Jumlah subjek kelompok eksperimen adalah 24 orang yang terdiri dari 15 wanita dan 9 laki-laki sedangkan jumlah subjek dalam kelompok kontrol adalah 25 orang yang terdiri dari 13 wanita dan 12 laki-laki. Pada awalnya jumlah subjek dalam kelompok eksperimen adalah 25 orang, namun ada 1 orang yang mengundurkan diri. Pelatihan ini terdiri dari 11 materi dengan keseluruhan penyajian selama empat hari dengan total jumlah sesi sebanyak 13 sesi dengan durasi waktu setiap sesinya selama empat jam efektif. Pelatihan ini melibatkan 2 pelatih dan 2 pendamping pelatih. Di bawah ini disajikan jadwal kegiatan pelatihan komunikasi interpersonal. 
Tabel 2. Jadwal Kegiatan Pelatihan Komunikasi Interpersonal

\begin{tabular}{|c|c|c|}
\hline \multicolumn{3}{|c|}{ Hari Pertama } \\
\hline Sesi & Materi & Tujuan \\
\hline 1 & Pembukaan & $\begin{array}{l}\text { - Peserta saling mengenal satu dengan yang lain } \\
\text { - Peserta mengungkapkan harapan mengikuti pelatihan } \\
\text { - Peserta mengetahui kelebihan dan kelemahan dirinya. } \\
\text { - Merumuskan visi dan misi menjadi seorang pelatih }\end{array}$ \\
\hline II & Empati & $\begin{array}{l}\text { Memahami pengertian dan perasaan orang lain tanpa } \\
\text { meninggalkan sudut pandang sendiri tentang hal yang } \\
\text { menjadi bahan komunikasi. }\end{array}$ \\
\hline III & Perspektif Sosial & $\begin{array}{l}\text { Mampu meramalkan perilaku apa yang sebaiknya } \\
\text { diambil, dan dapat menyiapkan tanggapan kita yang tepat } \\
\text { dan efektif. }\end{array}$ \\
\hline \multicolumn{3}{|c|}{ Hari Kedua } \\
\hline Sesi & Materi & Tujuan \\
\hline IV & Kepekaan & $\begin{array}{l}\text { Menetapkan perilaku mana yang diterima dan perilaku } \\
\text { mana yang tidak diterima oleh rekan yang berkomunikasi } \\
\text { dengan kita. }\end{array}$ \\
\hline V & $\begin{array}{l}\text { Pengetahuan } \\
\text { situasi komunikasi }\end{array}$ & $\begin{array}{l}\text { Menetapkan kapan dan bagaimana masuk dalam } \\
\text { percakapan, menilai isi dan cara berkomunikasi pihak } \\
\text { yang berkomunikasi dengan kita, dan selanjutnya } \\
\text { mengolah pesan yang kitaterima. }\end{array}$ \\
\hline VI & Monitoring diri & $\begin{array}{l}\text { Membantu menjaga ketepatan perilaku dan jeli } \\
\text { memperhatikan pengungkapan diri orang yang } \\
\text { berkomunikasidengan kita. }\end{array}$ \\
\hline \multicolumn{3}{|c|}{ Hari Ketiga } \\
\hline Sesi & Materi & Tujuan \\
\hline VII & $\begin{array}{l}\text { Keterlibatan } \\
\text { Interaktif }\end{array}$ & $\begin{array}{l}\text { Kecakapan ini menentukan tingkat keikutsertaan dan } \\
\text { partisipasi dalam komunikasi dengan orang lain. Meliputi: } \\
\text { sikap tanggap, sikap perseptif (sikap dimana kita } \\
\text { memahami bagaimana orang lain mengartikan perilaku } \\
\text { kita dan tahu bagaimana kita mengartikan perilakunya), } \\
\text { dan sikap penuh perhatian. }\end{array}$ \\
\hline VIII & $\begin{array}{l}\text { Manajemen } \\
\text { Interaksi }\end{array}$ & $\begin{array}{l}\text { Kecakapan mengambil tindakan, misalnya: kapan } \\
\text { mengambil inisiatif untuk mengawali topik baru, dan } \\
\text { kapan mengikutisaja topik yang dikemukakan orang lain. }\end{array}$ \\
\hline IX & Keluwesan Perilaku & $\begin{array}{l}\text { Mampu melaksanakan berbagai kemungkinan yang } \\
\text { dapat diambil untukmencapai tujuan komunikasi. }\end{array}$ \\
\hline
\end{tabular}




\begin{tabular}{|c|c|c|}
\hline \multicolumn{3}{|c|}{ Hari Keempat } \\
\hline Sesi & Materi & Tujuan \\
\hline$x$ & Mendengarkan & $\begin{array}{l}\text { Dapat mendengarkan orang lain tidak hanya isi, tetapi } \\
\text { juga perasaan, keprihatinan, dan kekhawatiran yang } \\
\text { menyertainya. }\end{array}$ \\
\hline XI & Gaya Sosial & $\begin{array}{l}\text { Membantu untuk dapat berperilaku menarik, khas, dan } \\
\text { dapat diterima dengan orang yang berkomunikasi } \\
\text { dengan kita. }\end{array}$ \\
\hline XII & $\begin{array}{l}\text { Kecemasan } \\
\text { Komunikasi }\end{array}$ & $\begin{array}{l}\text { Dapat mengatasi rasa takut, bingung dan kacau pikiran, } \\
\text { tubuh gemetar, dan rasa demam panggung yang muncul } \\
\text { dalam komunikasi dengan orang lain. }\end{array}$ \\
\hline XIII & Penutup & $\begin{array}{l}\text { - Peserta mengungkapkan apa yang dipikirkan dan } \\
\text { dirasakan selama mengikuti pelatihan } \\
\text { - Pengukuran efikasi diri setelah diberi perlakuan } \\
\text { - Peserta mengisi lembar evaluasi pelatihan dan } \\
\text { memberikan kritik dan saran. }\end{array}$ \\
\hline
\end{tabular}

Setelah pascates dilakukan, kemudian peneliti melakukan pelatihan pada kelompok kontrol pada minggu berikutnya, selain itu pada kelompok eksperimen juga dilakukan pengukuran tindak lanjut (follow-up).

\section{Metode Analisis Data}

Analisis data yang digunakan adalah independent sample t-test yaitu untuk menguji ada tidaknya perbedaan efikasi diri antara kelompok eksperimen dan kelompok kontrol, dan menggunakan teknik paired sample t-test untuk mengetahui ada tidaknya perbedaan antara sebelum dan sesudah pemberian perlakuan pada kelompok eksperimen dan untuk menguji ada tidaknya perbedaan antara pascates dengan pengukuran tindak lanjut pada kelompok eksperimen.

\section{Hasil Penelitian}

Data diperoleh dari 24 orang anggota kelompok eksperimen dan 25 orang anggota kelompok kontrol.

\section{Data Deskripsi Statistik}

Tabel 3 menunjukkan deskripsi subjek penelitian. 
Tabel 3. Deskripsi Subyek Penelitian

\begin{tabular}{llllll}
\hline \multicolumn{1}{c}{ Subjek } & Skor & Min & Max & Mean & $\begin{array}{c}\text { Standard } \\
\text { Deviation }\end{array}$ \\
\hline Kelompok & Prates & 64 & 81 & 71.08 & 4,745 \\
Eksperimen & Pascates & 76 & 95 & 85.29 & 4,319 \\
& Follow up & 80 & 95 & 87.29 & 3,791 \\
Kelompok & Prates & 54 & 75 & 63.88 & 5,747 \\
Kontrol & Pascates & 55 & 73 & 63.68 & 5,154 \\
\hline
\end{tabular}

Hasil Uji Hipotesis.

Analisis uji hipotesis dilakukan dengan tiga cara yaitu:

1. Hasil Independent Sample t-test dengan menggunakan skor perolehan (gain score) diperoleh $t=16,989(p<0,01)$ dengan demikian terdapat perbedaan yang signifikan pada efikasi diri sebagai pelatih antara kelompok eksperimen dan kelompok kontrol. Kelompok eksperimen mempunyai efikasi diri sebagai pelatih yang lebih tinggi dibandingkan kelompok kontrol dengan rata-rata efikasi diri sebagai pelatih pada kelompok eksperimen sebesar 14,21 dan kelompok kontrol sebesar 0,20.

2. Uji Paired Sample t-test dengan data prates dan pascates pada kelompok eksperimen menunjukkan skor $\mathrm{t}=-16,819(p<0,01)$, artinya ada perbedaan efikasi diri sebagai pelatih antara sebelum dan sesudah mengikuti pelatihan komunikasi interpersonal. Efikasi diri sebagai pelatih sesudah pelatihan lebih tinggi dibandingkan sebelum pelatihan, hal ini ditunjukkan dengan skor rata-rata pascates adalah sebesar 85,29 sedangkan rata-rata prates adalah sebesar 71,08 .

3. Uji Paired Sample t-test dengan data prates dan pengukuran tindak lanjut pada kelompok eksperimen menunjukkan skor $\mathrm{t}=-20,717(\mathrm{p}<0,01)$, artinya kelompok ekperimen tetap mengalami peningkatan efikasi diri sebagai pelatih dalam jangka waktu 20 hari setelah pelatihan. Efikasi diri sebagai pelatih tahap pengukuran tindak lanjut lebih tinggi dibandingkan sebelum pelatihan, hal ini ditunjukkan dengan skor rata-rata pengukuran tindak lanjut adalah sebesar 87,13 sedangkan rata-rata prates adalah sebesar 71,08 . 


\section{Pembahasan}

Tinggi rendahnya efikasi diri seseorang dipengaruhi oleh beberapa faktor. Bandura (1997) mengungkapkan faktor yang mempengaruhi efikasi diri adalah (a) sifat tugas yang dihadapi, yaitu semakin kompleks dan sulit sesuatu bagi seseorang maka semakin besar keraguan terhadap kemampuannya. Sebaliknya jika seseorang dihadapkan pada tugas yang sederhana dan mudah maka dirinya yakin pada kemampuannya untuk berhasil, (b) insentif eksternal yaitu adanya insentif berupa penghargaan (reward) dari orang lain untuk merefleksikan keberhasilan individu dalam menguasai atau melaksanakan tugas akan meningkatkan efikasi dirinya, (c) status individu dalam lingkungan, yaitu seseorang yang mempunyai status sosial lebih tinggi akan memiliki tingkat efikasi diri yang lebih tinggi pula dibandingkan dengan yang berstatus sosial rendah. Seseorang yang mempunyai status sosial tinggi membuat individu memperoleh penghargaan lebih dari orang yang dihormatinya, sehingga memberikan pengaruh pada efikasi dirinya, (d) informasi tentang kemampuan diri, efikasi diri akan meningkat jika individu mendapat informasi positif tentang dirinya, efikasi diri akan menurun jika individu mendapatkan informasi negatif mengenai kemampuannya.

Pelatihan komunikasi interpersonal yang disajikan sebanyak 13 sesi yang membahas tentang ketrampilan komunikasi interpersonal bagi seorang pelatih. Sesi pertama kesadaran diri (self awareness). Yang akan mengajak peserta untuk memahami kelebihan dan kelemahan dirinya sehingga seseorang akan mampu mengoptimalkan potensi yang dimilikinya dan meminimalisir kelemahan yang ada. Menurut Bandura (1997), efikasi diri akan muncul ketika individu mengetahui informasi yang positif tentang dirinya. Dengan adanya kesadaran diri akan kelebihan-kelebihan yang dimiliki, maka efikasi diri dalam diri seseorang akan mulai berkembang. Pelatihan Sesi dua sampai dengan sesi dua belas memberikan keterampilan komunikasi interpersonal yaitu kemampuan empati, perpektif sosial, kepekaan, pengetahuan akan situasi pada saat berkomunikasi, memonitor diri, keterlibatan interaktif, manajemen interaksi, keluwesan perilaku, kemampuan mendengarkan, gaya sosial, dan kecemasan komunikasi. Semua keterampilan tersebut memberikan gambaran tentang kompetensi komunikasi interpersonal yang dibutuhkan untuk menjadi seorang pelatih. Oleh karena itu peserta akan mengetahui gambaran tugas-tugas penyampaian pesan dari seorang pelatih kepada peserta pelatihan. Dengan adanya wawasan tentang tugas tersebut maka akan tercipta persepsi positif pada diri individu bahwa tugas komunikasi interpersonal seorang pelatih adalah sesuatu yang dapat dilatih sehingga akan terkesan mudah dan sederhana. Hal ini akan memberikan keyakinan pada diri individu bahwa ia mempunyai kemampuan untuk melakukan komunikasi interpersonal dengan orang lain. Hal ini sesuai dengan pendapat 
Bandura (1997) bahwa ketika seseorang mengetahui tugasnya dan mempersepsi tugas tersebut adalah sederhana dan mudah maka dirinya akan sangat yakin pada kemampuannya untuk berhasil, dengan kata lain akan meningkatkan efikasi dirinya. Hal ini juga sesuai dengan pendapat Pajares \& Schunk (1991) yang menjelaskan bahwa efikasi diri adalah bagian dari konsep diri yang merupakan keyakinan seseorang akan kemampuannya untuk mengarahkan tugas secara efektif dan melakukan tindakan yang diperlukan. Efikasi diri tidak berhubungan dengan kapasitas kemampuan seseorang, melainkan dengan penilaian tentang apa yang dapat dilakukan oleh dirinya (Brehm \& Kassin, dalam Mun, 2000).

Pendekatan pelatihan yang menggunakan metode belajar dari pengalaman (experiential learning) akan memberikan banyak kesempatan pada peserta pelatihan untuk belajar dari pengalaman. Hal ini diterapkan pada setiap sesi, di mana selalu ada materi bermain peran (role play). Bermain peran dimaksudkan untuk memberikan kesempatan merasakan secara langsung apa yang dipelajari sehingga individu dapat menarik kesimpulan dengan tepat mengenai konsep-konsep komunikasi interpersonal yang disampaikan oleh pelatih. Hal ini memungkinkan peserta pelatihan mengukur kemampuan yang dimilikinya, semakin ia yakin dengan kemampuan yang dimilikinya maka semakin tinggi efikasi dirinya.

Setelah proses bermain peran, peserta training akan mendapatkan umpan balik (feedback) dari pelatih maupun dari peserta pelatihan yang lain. Hal ini akan memberikan semangat pada diri seseorang ketika ia mendapatkan insentif atau penghargaan dari orang lain. Menurut Bandura (1997), jika seseorang mendapatkan intensif dari orang lain terhadap keberhasilan yang dilakukannya (competence contingent insentive) maka akan meningkatkan efikasi dirinya.

Dengan penjelasan di atas, maka dapat dilihat dinamika pengaruh pelatihan komunikasi interpersonal terhadap efikasi diri sebagai pelatih. Hal ini juga diperkuat dengan hasil wawancara yang menunjukkan bahwa subjek merasa yakin dapat berhasil menjadi pelatih yang handal karena menyadari kelebihan dan kelemahannya sehingga akan senantiasa belajar terus untuk mengurangi kelemahan dirinya. Pelatihan komunikasi interpersonal yang diikuti memberikan ketrampilan dasar untuk mampu berbicara di depan umum dan cara menyampaikan pesan atau informasi secara efektif kepada penyimak (audience). Dengan mendapatkan materi komunikasi interpersonal dan adanya latihan peran maka ia mempunyai gambaran tentang pekerjaan sebagai pelatih sehingga menumbuhkan keyakinan dalam dirinya. 


\section{Simpulan dan Rekomendasi}

Berdasarkan analisis yang dilakukan, dapat disimpulkan bahwa pelatihan komunikasi interpersonal terbukti meningkatkan efikasi diri sebagai pelatih pada subjek penelitian.

Berdasarkan kesimpulan tersebut dapat direkomendasikan kepada mahasiswa yang ingin menjadi pelatih untuk mengadopsi materi-materi yang disampaikan dalam pelatihan komunikasi interpersonal sebagai usaha untuk meningkatkan efikasi diri sebagai pelatih.

Bagi peneliti selanjutnya, peneliti merekomendasikan untuk menggunakan subjek yang lebih banyak lagi sehingga hasil analisis statistiknya lebih meyakinkan dan waktu untuk pengambilan data tindak lanjut dapat lebih dari 20 hari agar efektivitas sebuah pelatihan dapat lebih meyakinkan.

\section{Daftar Pustaka}

Alwisol. 2006. Psikologi Kepribadian. Malang: UMM Press.

Ancok, D. 2002. Outbond Management Training. Yogyakarta: Ull Press.

Bandura, A. 1997. Self Efficacy: The Exercise of Control. New York: W.H Freeman Company.

Barus, G. 2005. Komunikasi Interpersonal Suami-Istri Menuju Keluarga Harmonis. Jurnal Intelektual, 3, 137-152.

Carbery, R. \& Garavan, N.T. 2005. Organizational Restructuring and Downsizing: Issues Related to Learning, training and Employability of Survivors. Journal of European Industrial Training, 29, 488-510.

De Vito, J.A. 1997. Komunikasi Antarpribadi. Jakarta: Professional Books.

Dimyati. 2000. Kohesivitas Tim dan Efikasi Diri Sebagai Prediktor Prestasi Olahraga Tim. Psikologika, 5, 33-45.

Feldman, R. S. 1997. Social Psychology. $2^{\text {nd }}$ ed. New Jersey: Prentice-Hall Inc.

Hardjana, A.M., 2001. Training SDM yang Efektif. Yogyakarta: Kanisius

Hardjana, A. M. 2003. Komunikasi Intarpersonal dan Interpersonal. Yogyakarta: Kanisius.

Mun, Y.Y., 2000. Role of computer self efficacy in predicting user acceptance and use of information technology.myi@business.umd.edu.

Myers, D. G. 2005. SocialPsychology. $8^{\text {th }}$ ed. New York: McGraw-Hill

Pajares, F \& Schunk, D.H. 2001. Self-beliefs and School Success: Self-efficacy, Self-concept, and School Achievement. London:Ablex Publishing. 
Woolfolk, A. 2004. Educational Psychology. USA:Allyn and Bacon.

Yorke, M., \& Harvey, L. 2005. Graduates Attributes and Their Development. New Direction for Institutional Research. No.128. diunduh pada 19 Februari, 2007, dari http://search.ebscohost.com/19/02/2007 